\title{
Resistant moulds as pasteurization target for cold distributed high pressure and heat assisted high pressure processed fruit products
}

\author{
Filipa V.M. Silva ${ }^{a, *}$, Evelyn $^{b}$ \\ ${ }^{a}$ LEAF, Instituto Superior de Agronomia, Universidade de Lisboa, Tapada da Ajuda, 1349-017, Lisboa, Portugal \\ ${ }^{\mathrm{b}}$ Department of Chemical Engineering, University of Riau, Pekanbaru, 28293, Indonesia
}

\section{A R T I C L E I N F O}

\section{Keywords:}

HPP

High pressure thermal processing

Juices

Byssochlamys nivea

Neosartorya fischeri

Spores

\begin{abstract}
A B S T R A C T
High pressure processing (HPP), also known as high hydrostatic pressure (HHP) is a modern method of food pasteurization used commercially in many countries. It relies on the application of very high pressures (up to $600 \mathrm{MPa}$ ) to the food/beverage to inactivate microorganisms. Since no heat or mild heat is applied, most of the original food sensory, nutrient and functional properties are retained after processing, and fresh-like fruit products with longer shelf-life are produced. In this study, a review of the resistance to HPP and HPTP (high pressure thermal process) of key bacteria, moulds and yeasts which often contaminate fruit products was undertaken. Spores of moulds Byssochlamys nivea - anamorph name Paecilomyces niveus or Neosartorya fischeri anamorph name Aspergillus fischeri, are very resistant. A HPTP process of $600 \mathrm{MPa}-75^{\circ} \mathrm{C}-15$ min only caused a reduction of $1.4 \mathrm{log}$. Moulds are able to grow at temperatures between 10 and $43{ }^{\circ} \mathrm{C}$, water activity between 0.892 and 0.992 , over a wide range of $\mathrm{pH}(3-8)$, under reduced oxygen conditions inside food packs and in carbonated beverages, sometimes producing mycotoxins. Furthermore, HPP treated fruit products are cold stored, and therefore moulds can be an issue as they grow at temperatures as low as $10^{\circ} \mathrm{C}$. Therefore, in view of the acidity of fruit products, the high resistance to HPTP in particular older spores, the use of $B$. nivea or $N$. fischeri spores as reference microorganisms in the design of new HPP and HPTP processes with fruit products was proposed.
\end{abstract}

\section{Introduction to high pressure processing and food pasteurization}

Sustainable food process engineering refers to the efficient use of resources for food production. Therefore, food processes that are more efficient in terms of the consumption of raw materials, energy, water or other utilities are more sustainable. High pressure processing (HPP) for fruit products is a sustainable pasteurization technology and will be the focus of this study. Milani et al. (2016) concluded HPP technology at room temperature was enough to inactivate yeast in beer which requiried only half of the energy needed for standard thermal pasteurization of beer at $60{ }^{\circ} \mathrm{C}$. In addition pasteurized juices, pulps, or other fruit products last longer than the original raw fruits, which are perishable, with limited postharvest life and high rates of decay throughout the postharvest distribution chain (Silva et al., 1999; Brecht et al., 2003). Lastly, as opposed to food chemical preservatives/additives, a physical process such HPP is also more sustainable in terms of a lower impact to human health and the environment.
HPP is a commercial batch pasteurization technology in which packed fruit products such as juices, nectars, smoothies and purées are submitted to a high level of isostatic pressure (300-600 MPa) to inactivate microorganisms. This modern method of pasteurization is also known as high hydrostatic pressure (HHP) because the packed food is submerged in water inside the HPP container for processing. As opposed to rigid containers (e.g. glass, metal), most flexible films used for sterilized, dried or modified atmosphere packaged foods with extended shelf-life are also suitable for HPP foods (Dobiáš and Vápenka, 2018). Hiperbaric SA and Avure have sold each more than 100 industrial units worldwide and high pressure vessels of $525 \mathrm{~L}$ of capacity already can reach a throughput of $3000 \mathrm{~kg}$ or litres of packaged food per hour (Balda, 2018). As the process is a cold pasteurization (usually no heat employed, non-thermal process), the effect on food nutrients and sensory properties is negligible/minimal which makes this technology very appropriate to fruit products (Houška and Silva, 2018). Thus most of the original food sensory, nutrient and functional properties are retained, and fresh-like fruit products with longer shelf-life are produced. For

\footnotetext{
* Corresponding author. LEAF, Instituto Superior de Agronomia, Universidade de Lisboa, Tapada da Ajuda, 1349-017, Lisboa, Portugal.

E-mail addresses: filipavinagresilva@gmail.com (F.V.M. Silva), evelyn@unri.ac.id (Evelyn).
} 
example, no difference was detected by a wine expert sensory panel between red wine processed by HPP and untreated wine (van Wyk et al., 2018). As a consequence there are numerous HPP commercial fruit juices, smoothies and purées of attractive colours obtained from a single fruit or a mix of several fruit origins (Houška and Pravda, 2018). Regulatory aspects for HPP foods can vary across the globe, while for United States and Canada the process itself was approved, in European Union HPP products are considered novel foods and demonstration of safety in terms of pathogen reduction is required (Koutchma and Warriner, 2018).

Generally, heat in combination with HPP is required for extra microbial inactivation or the inactivation of spores, the resistant form that some bacteria, moulds and yeasts can produce under adverse conditions. HPTP is the high pressure thermal processing or heat assisted HPP process. Although there are several studies on the combined effects of pressure and temperature on microorganisms (Silva and Evelyn, 2018) and enzymes in foods (Terefe and Buckow, 2018), and quality parameters of foods, the commercial application of heat assisted HPP (HPTP) is still limited due to operating costs and issues with equipment maintenance such as seal replacement, poppets, valves, tubing, plug rings, etc. HPP products are cold distributed and stored, requiring a temperature below $7{ }^{\circ} \mathrm{C}$ to control the growth of possible microbes surviving the pasteurization process.

The guidelines previously recommended by Silva and Gibbs (2009) and Silva et al. (2014) for developing new food pasteurization processes can be adapted to cold-stored HPP fruit products:

(i) Identify microorganism(s) of public health concern and able to spoil the new fruit product.

(ii) Select the most resistant microorganism that is likely to survive the HPP or HPTP process as pasteurization reference.

(iii) Set a P-value (pasteurization value) in minutes resulting in 6 or more log reductions in the most resistant microbe, assuming the constant pressure phase of the HPP or HPTP cycle as the processing time.

(iv) Determine experimentally the inactivation of the selected microbe in the new food for different processing conditions, and assess the real process impact on the microbial survival.

(v) Define the pressure, temperature (if needed) and processing time for the new pasteurization process.

(vi) Validate the efficacy of the pasteurization process by performing storage tests under refrigerated storage conditions and for the intended shelf-life.

(vii) Use preservatives for additional safety or longer shelf-life.

The pasteurization targets (point i) are those microorganisms able to grow in high acidic fruit products. Therefore they are similar for HPP or thermal pasteurization processes of fruit products, and will be discussed in detail in Section 2. The critical HPTP process parameters for microbial inactivation include the initial food temperature, the process pressure during the constant pressure phase, the process time during the constant pressure phase and the average temperature during the constant pressure phase (Evelyn and Silva, 2018; Silva and Evelyn, 2018). As opposed to thermal processes, come up time for HPP and HPTP processes are quite quick. For example it took $\leq 1.5 \mathrm{~min}$ for the water in the HPP chamber to reach $600 \mathrm{MPa}-60{ }^{\circ} \mathrm{C}$ (Evelyn and Silva, 2016) and 600 MPa-70 ${ }^{\circ} \mathrm{C}$ (Evelyn and Silva, 2015a), while only 40 s were enough to reach $200 \mathrm{MPa}$ for a room temperature HPP process of wine (van Wyk and Silva, 2017a, 2017b). Therefore, inactivation during HPP process come up time is not considered (point iii), as only marginal microbial inactivation can occur. Generally, the reviews in the area of pasteurization only consider the constant pressure phase of the HPP cycle. Other factors such as the presence of added $\mathrm{CO}_{2}$ (e.g. carbonated beverages) require extra care, especially during decompression to avoid package bursting (Milani and Silva, 2016; Milani et al., 2016; van Wyk and Silva, 2017b).
Table 1

Examples of undesirable microorganisms in high acidic fruit products.

\begin{tabular}{|c|c|c|c|}
\hline $\begin{array}{l}\text { Spore cells } v s \\
\text { Vegetative } \\
\text { cells }\end{array}$ & $\begin{array}{l}\text { Type of } \\
\text { microorganism }\end{array}$ & $\begin{array}{l}\text { Spoilage } v s \\
\text { Pathogen }\end{array}$ & Scientific name \\
\hline Spores & Fungi - moulds & Spoilage & $\begin{array}{l}\text { Byssochlamys nivea } \\
\text { Byssochlamys fulva } \\
\text { Byssochlamys spectabilis } \\
\text { Neosartorya fischeri } \\
\text { Talaromyces avellaneus } \\
\text { Eupenicillium javanicum } \\
\text { Eurotium repens } \\
\text { Penicillium expansum }\end{array}$ \\
\hline Spores & Bacteria & Spoilage & $\begin{array}{l}\text { Alicyclobacillus } \\
\text { acidoterrestris } \\
\text { Bacillus subtilis } \\
\text { Bacillus licheniformis } \\
\text { Bacillus megaterium } \\
\text { Bacillus coagulans } \\
\text { Bacillus thuringiensis } \\
\text { Clostridium botyricum } \\
\text { Clostridium pasteurianum }\end{array}$ \\
\hline Spores & Fungi - yeasts & Spoilage & $\begin{array}{l}\text { Zygosaccharomyces bailii } \\
\text { Saccharomyces cerevisiae }\end{array}$ \\
\hline Vegetative & Bacteria & $\begin{array}{l}\text { Pathogens } \\
\text { resistant to acidic } \\
\text { environments }\end{array}$ & $\begin{array}{l}\text { Salmonella } \\
\text { Esherichia coli } 0157: H 7\end{array}$ \\
\hline Vegetative & Bacteria & $\begin{array}{l}\text { Spoilage lactic } \\
\text { acid bacteria } \\
\text { (LAB) }\end{array}$ & $\begin{array}{l}\text { Leuconostoc } \\
\text { mesenteroides } \\
\text { Lactobacillus brevis } \\
\text { Lactobacillus plantarum } \\
\text { Lactobacillus fermentum }\end{array}$ \\
\hline
\end{tabular}

The main objectives of this study were: (i) to search and select appropriate microbial targets for HPP pasteurization processes of highacid cold distributed fruit products, (ii) to compare the HPP/HPTP resistance and inactivation pattern of key bacteria, moulds and yeasts in fruit products, (iii) to ensure vegetative pathogens are inactivated by mild HPP, and (iv) to propose moulds spores as reference to design HPP pasteurization processes of fruit products.

\section{Pasteurization targets: undesirable microbes able to grow in high acidic fruit products}

Raw foods and beverages contain microorganisms. Food spoilage can be caused by unwanted microbial growth, as microbial activity changes the original food properties, namely the acidity and the overall flavour. Foodborne illnesses occur only when people eat or drink food/beverages which are contaminated with pathogens (the "bad" microbes), chemicals, or toxins, above a certain concentration which is harmful to humans. While some pathogenic microorganisms can cause themselves foodborne infection if they grow to certain levels (e.g. Escherichia coli, Salmonella, Listeria), others can produce toxins, causing foodborne intoxication (e.g. Clostridium botulinum). The following conditions must be met for a foodborne illness to happen: (i) the microorganism or its toxin must be present in food, (ii) the food must be suitable for the microorganism to grow, (iii) the temperature must be suitable for the microorganism to grow, (iv) enough time must be given for the microorganism to grow (and to produce a toxin), (v) the food must be eaten (Albrecht and Sumner, 1992; Silva et al., 2014; Silva and Gibbs, 2010).

Table 1 presents examples of microorganims in highly acidic fruit products which have been used as pasteurization criteria for fruit products (e.g. juices) thermal processes (Silva and Gibbs, 2009). Due to the presence of natural organic acids, fruit products are high acidic, and $\mathrm{pH}$ is normally below 4.6. This level of acidity prevents the growth of most vegetative bacterial pathogens, the germination and growth of pathogenic bacterial spores (Lopez, 1987) and the germination and growth of most spoilage bacterial spores such as the very resistant 


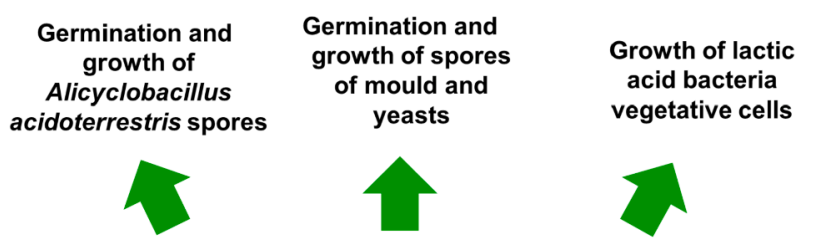

High acidity of fruit products $(\mathrm{pH}<4.6)$
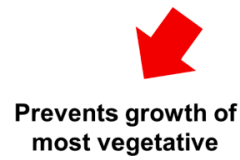

bacterial pathogens

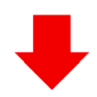

Prevents germination
and growth of and growth of bacterial spores

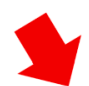

Prevents germination and growth of most spoilage bacterial spores

Fig. 1. Effect of the acidity of fruit products on the growth of different types of microbes.

Geobacillus stearothermophilus (Fig. 1) (Silva and Gibbs, 2004, 2009). However, Alicyclobacillus acidoterrestris, a thermoacidophilic, was reported in the eighthies as a new type of spoilage bacterium in aseptically packaged apple juice (Cerny et al., 1984; Deinhard et al., 1987). Splittstoesser et al. (1994) isolated acidic spore-forming bacilli from a spoiled apple juice, later identified as A. acidoterrestris. Spore germination and growth under acidic conditions was reported in orange, apple, and grapefruit juices stored at $30{ }^{\circ} \mathrm{C}$ (Pettipher et al., 1997). Based on these findings Silva and Gibbs (2001) suggested the use of A. acidoterrestris spores as the target of pasteurization processes in shelf-stable high-acidic fruit products. Lactic acid bacteria (LAB) can spoil juices but since they cannot produce spores they are easily inactivated by HPP alone (Silva and Evelyn, 2018).

Moulds (Beuchat, 1998; Rico-Munoz et al., 2019) and yeasts (Massaguer et al., 2014) can easily grow in the acidic environment found in fruit products, and at lower temperatures than bacteria. Due to the resistance of ascospores to pasteurization, Byssochlamys mould can be found in spoiled heat processed fruit products, namely $B$. fulva, B. nivea and $B$. spectabilis species (Kotzekidou, 2014). These moulds can grow at very low $\mathrm{O}_{2}$ concentration $(<0.5 \%)$ and at temperatures as low as $10{ }^{\circ} \mathrm{C}$.

Spores can last for long periods in a dormant stage until germination and growth occurs under favourable environmental conditions. Spores of the following microorganisms can germinate and grow in acidic fruit environments (Fig. 1), and will be the main focus of this study: (i) Alicyclobacillus acidoterrestris, (ii) moulds and (iii) yeasts. Those spoilage sporeformer organisms ferment the foods and produce off-flavours but are not a concern in terms of human health. In addition, and in view of a few outbreaks registered in the past, (iv) specific vegetative pathogens (Salmonella, Escherichia coli) will also be covered. The HPP and HPTP are alternative pasteurization methods to the conventional thermal processing (e.g. tetra-pak, canned) often used to inactivate the above mentioned microorganisms and preserve the fruit juices or other fruit products. The following section reviews the resistance of critical microbes to HPP and heat assisted HPP.

\section{Resistance of microbes to HPP and HPTP in fruit products}

3.1. HPP resistance of vegetative pathogens causing outbreaks in fresh fruit juices

Salmonella and E. coli 0157:H7 are resistant to acidic environments ( $\mathrm{pH}<4.6)$ and can survive for several weeks. Although most vegetative pathogens, even if present, are unable to grow in the acidic environment found in fruit products, their very low infectious dose $\left(10^{1}-10^{2} \mathrm{cfu} / \mathrm{ml}\right)$

Table 2

Resistance of different type of microbial spores to HPP alone and combined with heat (HPTP) in high acidic fruit products. ${ }^{\text {a }}$

\begin{tabular}{|c|c|c|c|c|c|c|c|c|}
\hline & Strain & $\begin{array}{l}\text { Sporulation } \\
\text { time }\end{array}$ & Fruit product & $\begin{array}{l}\text { Pressure } \\
(\mathrm{MPa})\end{array}$ & $\begin{array}{l}\text { Processing } \\
\text { temperature }\left({ }^{\circ} \mathrm{C}\right)\end{array}$ & $\begin{array}{l}\text { Holding time } \\
\text { (min) }\end{array}$ & $\begin{array}{l}\text { Log } \\
\text { reduction }\end{array}$ & Reference \\
\hline \multicolumn{9}{|c|}{$\begin{array}{l}\text { HEAT ASSISTED HPP (HPTP) } \\
\text { Moulds }\end{array}$} \\
\hline \multirow[t]{4}{*}{ Byssochlamys nivea } & $\begin{array}{l}\text { JCM } \\
12806\end{array}$ & 12 week & $\begin{array}{l}\text { Strawberry } \\
\text { puree }\end{array}$ & 600 & 75 & 15 & 1.4 & $\begin{array}{l}\text { Evelyn and Silva } \\
2017\end{array}$ \\
\hline & & 4 week & $\begin{array}{l}\text { Strawberry } \\
\text { puree }\end{array}$ & 600 & 75 & 15 & 1.7 & $\begin{array}{l}\text { Evelyn and Silva } \\
\text { 2015b }\end{array}$ \\
\hline & $\mathrm{nr}$ & 4.3 week & $\begin{array}{l}\text { Pineapple } \\
\text { nectar }\end{array}$ & 600 & 70 & 15 & 1.5 & Ferreira et al. (2009) \\
\hline & DSM 1824 & $\geq 4.3$ week & Grape juice & 700 & 70 & 15 & 3.2 & Butz et al. (1996) \\
\hline \multirow[t]{2}{*}{ Neosartorya fischeri } & JCM 1740 & 12 week & Apple juice & 600 & 75 & 15 & 1.4 & $\begin{array}{l}\text { Evelyn and Silva } \\
2017\end{array}$ \\
\hline & & 4 week & Apple juice & 600 & 75 & 15 & 3.7 & Evelyn et al. (2016) \\
\hline \multicolumn{9}{|l|}{ Bacteria } \\
\hline $\begin{array}{r}\text { Alicyclobacillus } \\
\text { acidoterrestris }\end{array}$ & $\begin{array}{l}\text { NZRM } \\
4098\end{array}$ & 2.6 week & Orange juice & 600 & 65 & 10 & 2.6 & Silva et al. (2012) \\
\hline Bacillus coagulans & $\begin{array}{l}\text { ATCC } \\
7050\end{array}$ & 1.4 week & Tomato pulp & 600 & 60 & 10 & 5.0 & $\begin{array}{l}\text { Zimmermann et al. } \\
\text { (2013) }\end{array}$ \\
\hline \multicolumn{9}{|c|}{ HPP AT ROOM TEMPERATURE (HPP) } \\
\hline Talaromyces avellaneus & $\mathrm{nr}$ & 8 week & Apple juice & 600 & - & 15 & 1.1 & Voldřich et al. (2004) \\
\hline Eurotium repens & $\begin{array}{l}\text { DSMZ } \\
62631\end{array}$ & 4 week & Apple juice & 500 & - & 15 & 4.2 & $\begin{array}{l}\text { Merkulow et al. } \\
\text { (2000) }\end{array}$ \\
\hline Penicillium expansum & $\begin{array}{l}\text { DSMZ } \\
1994\end{array}$ & 2 week & Apple juice & 350 & - & 15 & 6.0 & $\begin{array}{l}\text { Merkulow et al. } \\
(2000)\end{array}$ \\
\hline \multicolumn{9}{|l|}{ Yeasts } \\
\hline \multirow[t]{4}{*}{ Zygosaccharomyces bailii } & $\begin{array}{l}\text { ATCC } \\
36947\end{array}$ & 2 week & Grape juice & 300 & - & 15 & 0.5 & Raso et al. (1998) \\
\hline & & & Orange juice & 300 & - & 15 & 1.5 & \\
\hline & & & Apple juice & 300 & - & 15 & 1.5 & \\
\hline & & & $\begin{array}{l}\text { Pineapple } \\
\text { juice }\end{array}$ & 300 & - & 15 & 1.5 & \\
\hline \multirow[t]{2}{*}{ Saccharomyces cerevisiae } & YM-147 & 3 day & Orange juice & 500 & - & 1.1 & 6.0 & Zook et al. (1999) \\
\hline & & & Apple juice & 500 & - & 0.9 & 6.0 & \\
\hline
\end{tabular}

${ }^{a}$ Processing temperature was the average temperature during the constant pressure phase of the HPP cycle; spore age is the culture time for sporulation in appropriate agar or broth; $\mathrm{nr}$ - not reported. 


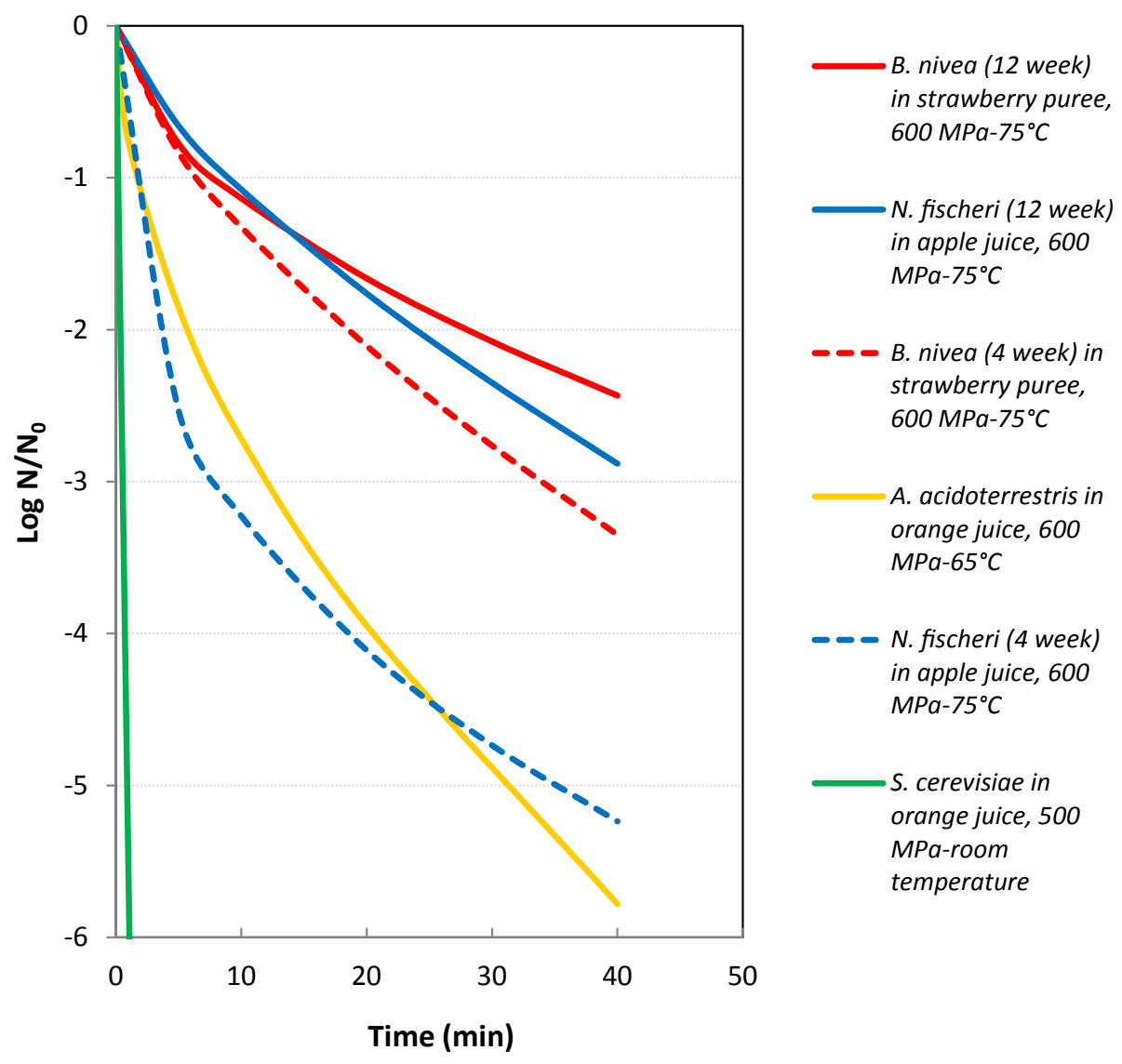

Fig. 2. HPP alone and combined with heat to inactivate spores of bacteria, moulds and yeast in fruit juices and purees.

could be a human health concern (FDA, 2011). For example Salmonella declines or does not grow in acidic environments ( $\mathrm{pH} 3.5$ to 4.4) (Parish et al., 1997). However there are exceptions with specific strains. An outbreak of Salmonella serovar Typhimurium was registered in unpasteurized orange juice in the United States (Jain et al., 2005). Teo et al. (2001) worked with Muenchen Salmonella (strain isolated from outbreaks in fresh unpasteurized orange juice) and observed $>8$ log reduction in orange and grapefruit juices, and $5 \log$ reduction in apple juice after a $615 \mathrm{MPa}-2$ min HPP process.

Additionally, in European Union the HPP products are considered novel foods, and they need to demonstrate safety in terms of pathogen reduction to be approved commercially. E. coli O157:H7 and Salmonella spp. decreased $>5 \log$ in strawberry puree after $400 \mathrm{MPa}-2 \mathrm{~min}$ (Huang et al., 2013). A HPP process of 5 min at 350 MPa fully inactivated ( $>8$ log reductions) Escherichia coli O157:H7 and a cocktail of the "big six" Shiga toxin-producing E. coli in strawberry puree (Hsu et al., 2014). However, Teo et al. (2001) conducted $615 \mathrm{MPa}-2$ min HPP inactivation studies using a cocktail of $3 \mathrm{E}$. coli strains (including SEA13B88 which was isolated from outbreaks in unpasteurized apple juice) suspended in grapefruit, orange and apple juices, which resulted in $>8,2$ and only 0.4 $\log$ reductions, respectively. This means that type of strain and fruit juice have a great effect on the resistance of the vegetative microbes. However, in general a process of $600 \mathrm{MPa}$ for $5 \mathrm{~min}$ at room temperature can ensure full inactivation ( $>7 \log$ ) of several strains of $E$. coli in different juices (Evelyn and Silva, 2018). A review of 23 studies carried out with meat and milk foods revealed the minimum temperature for Salmonella growth was $8^{\circ} \mathrm{C}$, while a similar review with $E$. coli O157:H7 reported a lower growth temperature of $6{ }^{\circ} \mathrm{C}$ for this microorganism (Hudson et al., 2011). As the HPP fruit products are cold stored and distributed $\left(<7^{\circ} \mathrm{C}\right)$ it is very unlikely that vegetative pathogens, even if surviving the HPP process (which from the above discussion it is also very unlikely to happen), will be able to grow under refrigeration, so they are not a major concern in this class of foods/beverages.

\subsection{Log reductions of microbial spores}

Table 2 shows a selection of microbial spore inactivation data collected from the literature in single-strength acidic juices (soluble solids $\leq 13^{\circ} \mathrm{Brix}, \mathrm{pH}<4.6$ ). Saccharomyces cerevisiae yeast spore was easily inactivated in orange and apple juices by room temperature HPP at $500 \mathrm{MPa}$ for about $1 \mathrm{~min}$ (6 log reductions) (Zook et al., 1999). Raso et al. (1998) only got 1.5 log reductions of Zygosaccharomyces bailii ascospores in orange, apple and pineapple juices after 15 min HPP process at $300 \mathrm{MPa}$, showing a pressure $>300 \mathrm{MPa}$ is required for yeast ascospore inactivation. On the contrary $300 \mathrm{MPa}-4 \mathrm{~min}$ HPP process caused $>4.0 \mathrm{log}$ reductions in the vegetative form of the same yeast. With respect to moulds there are varying results in which the resistance depends on the species and spore age. Groot et al. (2019) worked with orange juice containing Penicillium conidia and showed $400 \mathrm{MPa}-5 \mathrm{~min}$ caused $>7 \mathrm{log}$ reduction in conidia of 3 strains of Penicillium isolated from pulsed electric fields treated juices. Penicillium expansum conidiospore and Eurotium repens spores showed inactivation $(\geq 4.2 \log$ reductions) in apple juice by room temperature HPP at $500 \mathrm{MPa}$, although the authors claimed there is a more resistant (stable) fraction of the spores which is difficult to inactivate by HPP alone (Merkulow et al., 2000). Thus a two phase first order model (biphasic model) was suggested to incorporate the 2 rates of inactivation. HPP alone was not effective to inactivate Talaromyces avellaneus ascospores as only $1.1 \mathrm{log}$ reduction was achieved after $15 \mathrm{~min}$ at $600 \mathrm{MPa}$, so heat assisted process might be a better solution (Voldrich et al., 2004). The other studies carried out with Neosartorya fischeri and Byssochlamys nivea ascospores employed heat assisted HPP as they are very resistant moulds. Four week Neosartorya fischeri suspended in apple juice decreased by 3.7 log after a $600 \mathrm{MPa}-75^{\circ} \mathrm{C}-15 \mathrm{~min}$ process, while 12 week spore culture only 
Table 3

Equations describing the inactivation of different type and age of microbial spores after HPP alone or combined with heat (HPTP) ${ }^{\text {a }}$

\begin{tabular}{|c|c|c|c|c|c|c|c|c|}
\hline \multirow[t]{2}{*}{ Microbe } & \multirow[t]{2}{*}{ Food/beverage } & \multicolumn{2}{|c|}{ Processing conditions } & \multirow[t]{2}{*}{ Equation } & \multirow[t]{2}{*}{$b$} & \multirow[t]{2}{*}{$n$} & \multirow[t]{2}{*}{$D_{P, T}(\min )$} & \multirow[t]{2}{*}{ Reference } \\
\hline & & $P(M P a)$ & $T\left({ }^{\circ} \mathrm{C}\right)$ & & & & & \\
\hline Byssochlamys nivea (12 week) & Strawberry puree & 600 & 75 & $\log \frac{N}{N_{0}}=-0.32 t^{0.55}$ & 0.32 & 0.55 & - & Evelyn and Silva (2017) \\
\hline Neosartorya fischeri (12 week) & Apple juice & 600 & 75 & $\log \frac{N}{N_{0}}=-0.21 t^{0.71}$ & 0.21 & 0.71 & - & Evelyn and Silva (2017) \\
\hline Byssochlamys nivea (4 week) & Strawberry puree & 600 & 75 & $\log \frac{N}{N_{0}}=-0.29 t^{0.66}$ & 0.29 & 0.66 & - & Evelyn and Silva (2017) \\
\hline Alicyclobacillus acidoterrestris ${ }^{\mathrm{b}}$ & Orange juice & 600 & 65 & $\log \frac{N}{N_{0}}=-0.76 t^{0.55}$ & 0.76 & 0.55 & - & Silva et al. (2012) \\
\hline Neosartorya fischeri (4 week) & Apple juice & 600 & 75 & $\log \frac{N}{N_{0}}=-1.44 t^{0.35}$ & 1.44 & 0.35 & - & Evelyn and Silva (2017) \\
\hline Saccharomyces cerevisiae & Beer $0 \%$ alc/vol & 400 & No heat & $\log \frac{N}{N_{0}}=-2.09 t^{0.20}$ & 2.09 & 0.20 & - & Milani and Silva (2016) \\
\hline S. cerevisiae & Orange juice & 500 & No heat & $\log \frac{N}{N_{0}}=-\frac{t}{0.18}$ & - & - & 0.18 & Zook et al. (1999) \\
\hline S. cerevisiae & Apple juice & 500 & No heat & $\log \frac{N}{N_{0}}=-\frac{t}{0.15}$ & - & - & 0.15 & Zook et al. (1999) \\
\hline
\end{tabular}

${ }^{\text {a }}$ Equations are listed by decreasing resistance of microbial spores.

b Survival data from Silva et al. (2012) were remodelled using Weibull model.

underwent $1.4 \log$ reduction for the same process (Evelyn et al., 2016; Evelyn and Silva, 2017), showing the importance of spore age in their final resistance. Byssochlamys nivea spores seems to be even more resistant, showing a reduction of $3.2 \mathrm{log}$ in grape juice after 700 $\mathrm{MPa}-70^{\circ} \mathrm{C}-15 \mathrm{~min}$ (Butz et al., 1996), $1.5 \mathrm{log}$ in pineapple nectar after $600 \mathrm{MPa}-70^{\circ} \mathrm{C}-15 \mathrm{~min}$ (Ferreira et al., 2009). The spore culture time had less effect on $B$. nivea ascospores which exhibited 1.7 log reductions in strawberry puree after $600 \mathrm{MPa}-75^{\circ} \mathrm{C}-15 \mathrm{~min}$ for 4 week cultures and $1.4 \log$ reduction for 12 week sporulation in potato dextrose agar (Evelyn and Silva, 2015b, 2017).

Bacterial spores were also very resistant to HPTP. Alicyclobacillus acidoterrestris, an acid lover (Pinhatti et al., 1997), decreased only 2.6 log in orange juice after a HPTP process of $600 \mathrm{MPa}-65^{\circ} \mathrm{C}-10 \mathrm{~min}$ (Silva et al., 2012). Bacillus coagulans in tomato pulp was reduced by $5 \log$ with a $600 \mathrm{MPa}-60^{\circ} \mathrm{C}-10 \mathrm{~min}$ process (Zimmermann et al., 2013).

\subsection{Comparison of survival curves of moulds ascospores of different age} with bacterial and yeast spores

Fig. 2 shows examples of some survival curves (log $N / N_{o}$ vs time) for some microbial spores important for fruit products and Table 3 shows the equations fitted to different spores' inactivation. $S$. cerevisiae yeast ascospores exhibited log linear pattern with HPP processing time and were easily inactivated with HPP without heat $\left(D_{500} \mathrm{MPa}\right.$-values of 0.18 min in orange juice, Zook et al., 1999). The conventional first order kinetics (Equation (1)) often used for thermal inactivation was well suited:

$\log \frac{N}{N_{0}}=-\frac{t}{D_{P T}}$

where, $N_{0}$ is the initial, untreated microbial concentration in the food (cfu/ml or $\mathrm{cfu} / \mathrm{g}), N$ is the number of survivors after HPP or HPTP treatment for a specific time $t$ ( $\mathrm{min})$, and $D_{P, T}$-value is decimal reduction time, the time in min at a certain pressure $(P)$ and/or temperature $(T)$ necessary for $1 \log$ reduction in the microbial population $\left(N / N_{o}=0.1\right)$.

The other survival curves presented in Fig. 2 showed non-linearity and an upward concavity. A review on bacterial, mould and yeast spores inactivation by HPTP showed that non-linearity is more frequent than rare, and authors used Weibull, first order biphasic (two fractions), fractional conversion or second order polynomial models (Evelyn and Silva, 2019). As opposed to Zook et al. (1999), Milani and Silva (2016) observed non-linearity for $S$. cerevisiae ascospores HPP inactivation in beer $0 \%$ alc/vol and used the Weibull model. The authors fitted Equation (2) to $N / N_{o}$ vs time data and estimated by non-linear regression the parameters $b$ and $n$. From Fig. 2, the inactivation pattern of spores of moulds and bacteria submitted to HPP or HPP-thermal processes is similar, starting by a higher rate of microbial inactivation, which subsequently decreases with processing time. This undesirable phenomenon translates into an increase in the microbial resistance with processing time. As mentioned in previous section, some authors refer to a more resistant fraction of microbial spores which are harder to inactivate. The traditional chemical kinetic models are not applicable to this type of curve and authors used the Weibull model (Weibull, 1951) characterized by heterogeneity in the resistance distributed among individual cells within a population (Pin and Baranyi, 2006) (Eq. (2)):

$\log \frac{N}{N_{0}}=-b t^{n}$

where, $b$, the scale factor (rate parameter) is related to the rate at which the microorganism is inactivated; $n$, the survival curve shape factor, describes the degree of curvilinearity: usually $n<1$ corresponds to concave-upwards (tailings) in the survival curve and when $n=1$ the Weibull model becomes the simple first-order kinetic model.

Table 3 shows the equation and Weibull parameters $(b, n)$ estimated for the microbial survival curves presented in Fig. 2 and others. As mentioned previously $S$. cerevisiae spores were quickly and linearly inactivated at room temperature HPP. However, it was very hard to inactivate mould and bacterial spores, even using heat assisted $600 \mathrm{MPa}$ HPP at $75{ }^{\circ} \mathrm{C}$ (HPTP). The $n$ values (shape) between 0.20 and 0.71 (Table 3 ), confirmed the upward concavity visible on the survival curves of moulds and bacteria spores (Fig. 2) (difficult to inactivate). The aimed $6 \log$ pasteurization could not be achieved even with a long processing time of $40 \mathrm{~min}$. A. acidoterrestris bacterium spores seem less resistant than moulds as a similar survival curve was obtained at $600 \mathrm{MPa}-65{ }^{\circ} \mathrm{C}$ as opposed to $600 \mathrm{MPa}-75^{\circ} \mathrm{C}$ used for 4 weeks to accomplish $N$. fischeri mould inactivation. With these processing conditions, only about 3 log reductions were obtained after $10 \mathrm{~min}$. With respect to 12 week old $N$. fischeri spores and B. nivea ( 4 and 12 week spores), the inactivation is even less and very little, about only 1.1-1.3 log reductions after $10 \mathrm{~min}$ $600 \mathrm{MPa}-75{ }^{\circ} \mathrm{C}$ HPTP process. Different resistance among spores of different age could also indicate differences in the ratio of asci and ascospores, in which older cultures might contain more asci than free ascospores (thus more difficult to inactivate) (Evelyn and Silva, 2017).

\section{Use of Byssochlamys nivea (Paecilomyces niveus) or Neosartorya fischeri (Aspergillus fischeri) moulds spores for the design of HPP pasteurization processes in high acidic cold distributed fruit products}

As concluded yeast spores are not a concern because they are easily 

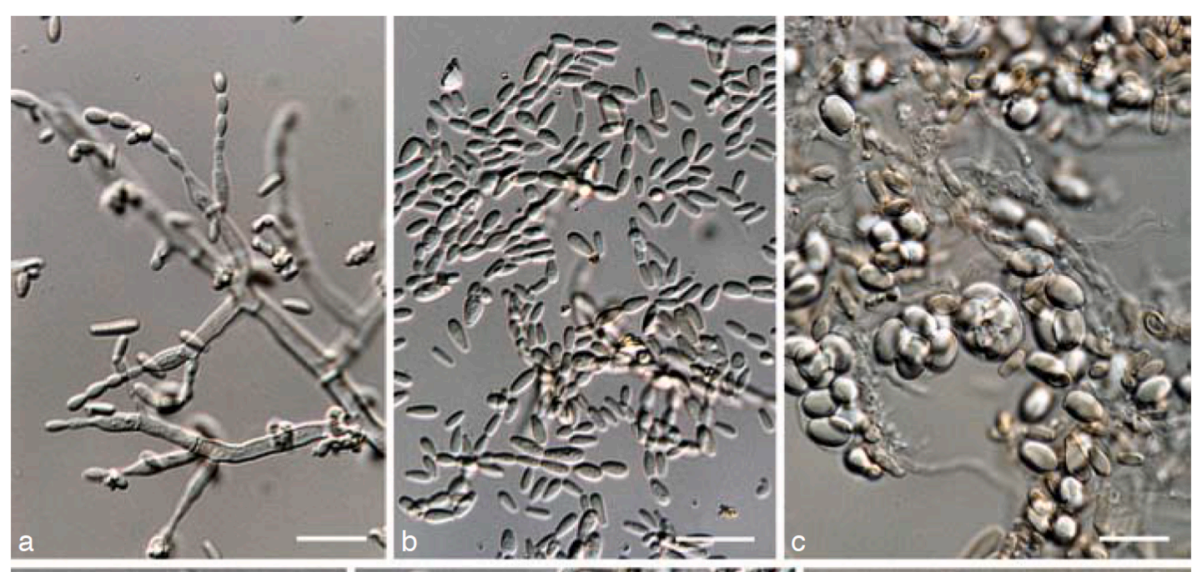

Fig. 3. Byssochlamys fulva. a. Conidiophores. b. Conidia. c. Asci and ascospores; Byssochlamys nivea. d. Conidiophores. e. Conidia. f. Ascospores; Byssochlamys verrucosa. g. Conidiophores. h. Conidia. i. Asci and ascospores. Scale bars $=10 \mu \mathrm{m}$. Fungi photos retrieved from Samson, R.A., Houbraken, J., Varga, J., Frisvad, J. C., 2009. Polyphasic taxonomy of the heat resistant ascomycete genus Byssochlamys and its Paecilomyces anamorphs. Persoonia 22, 14-27. With permission from Jos Houbraken, Westerdijk Fungal Biodiversity Institute.
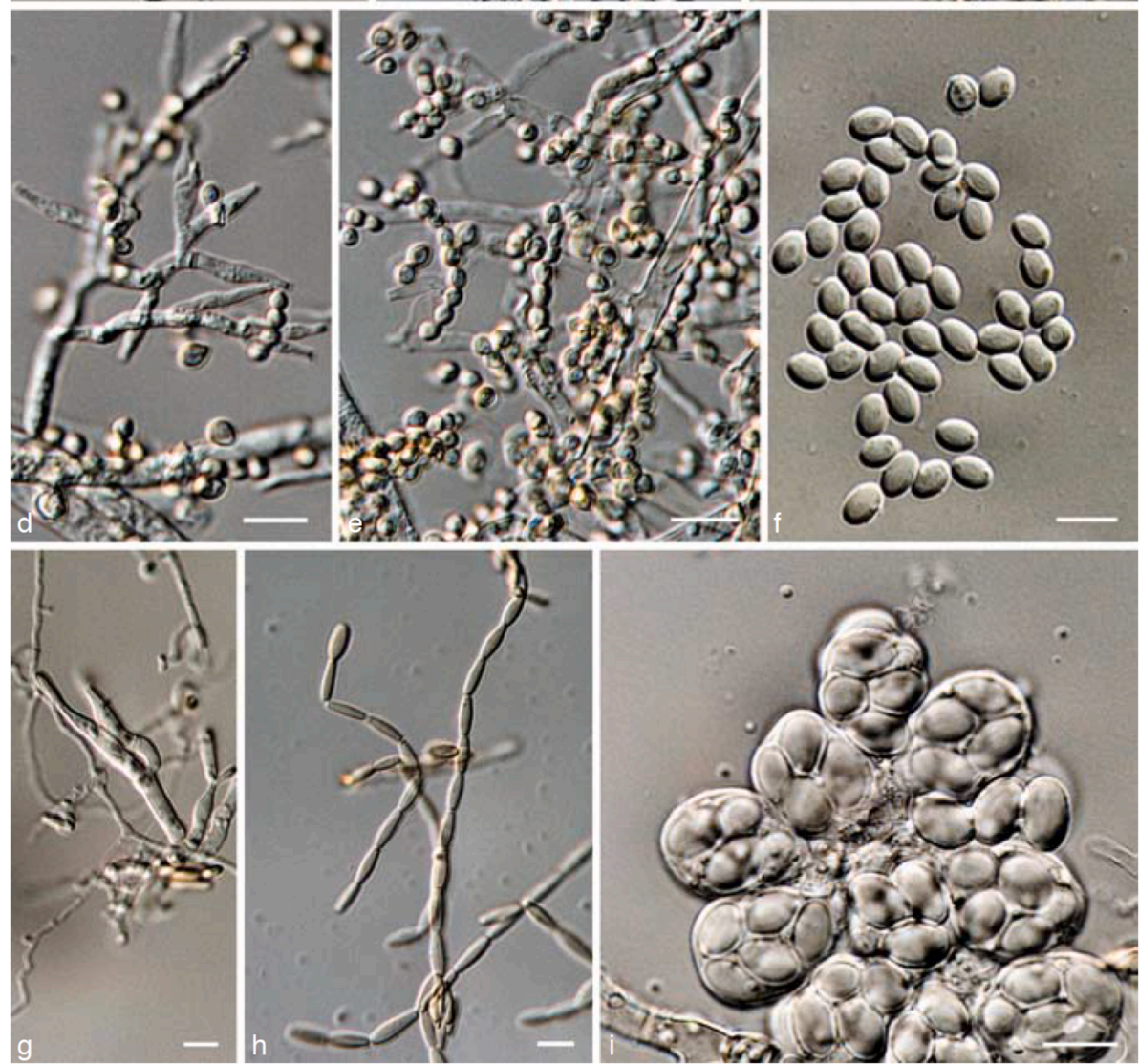

inactivated by room temperature HPP (Milani and Silva, 2016). HPP alone is not enough for the inactivation of most mould and bacterial spores in fruit products, and heat assisted HPP is required (HPTP = HPP-thermal) (Evelyn and Silva, 2019). The comparison of survival curves from different spore types showed that Byssochlamys nivea and Neosartorya fischeri mould ascospores are more resistant to HPP-thermal than A. acidoterrestris bacterial spores (Fig. 2). Also the resistance of moulds' spores increases with their age. Furthermore A. acidoterrestris is a thermoacidophilic organism (growth limited to temperatures ranging between 25 and $60{ }^{\circ} \mathrm{C}$ ) (Deinhard et al., 1987), not expected to grow under refrigerated conditions employed for storage and distribution of HPP products. Thus, moulds are more problematic than bacteria, as they can withstand lower temperatures.

The comparison of $600 \mathrm{MPa}-75{ }^{\circ} \mathrm{C}-10 \mathrm{~min}$ with thermal processing alone at $75^{\circ} \mathrm{C}-10$ min showed $1.4 \log$ reductions in $B$. nivea 4 week old spores for HPP-thermal vs. no inactivation for thermal (Evelyn and Silva, 2015b). Likewise, 4 week old $N$. fischeri spores reduced steadily with the processing time reaching nearly $4.3 \log$ after $20 \mathrm{~min}$, as opposed to $75^{\circ} \mathrm{C}$ thermal, in which no inactivation was registered (Evelyn et al., 2016). In fact, $75{ }^{\circ} \mathrm{C}$ causes a slight increase in spore numbers (colonies) counted in the agar plates. These findings demonstrated the advantage of heat assisted HPP (HPTP) over thermal process alone for inactivating these moulds' spores in fruit juices/pulps.

Byssochlamys nivea (anamorph name Paecilomyces niveus) and Neosartorya fischeri (anamorph name Aspergillus fischeri) are moulds that spoil acidic fruit products and can produce mycotoxins (Nielsen et al., 1989; Frisvad and Samson, 1991; Houbraken and Samson, 2017). B. nivea is responsible for patulin mycotoxin in apple juices (Kotzekidou, 2014). They are able to produce extremely resistant spores inside an ascus mother cell, named ascospores (each ascus contains typically 8 ascospores). The morphology of those and other mould structures are in the photographs shown in Fig. 3 (Byssochlamys fulva, Byssochlamys nivea and Byssochlamys verrucosa) and Fig. 4 (Neosartorya fischeri) (Samson et al., 2007, 2009). B. nivea ascospores are $4-5.5 \times 3-4 \mu \mathrm{m}$ presenting a 


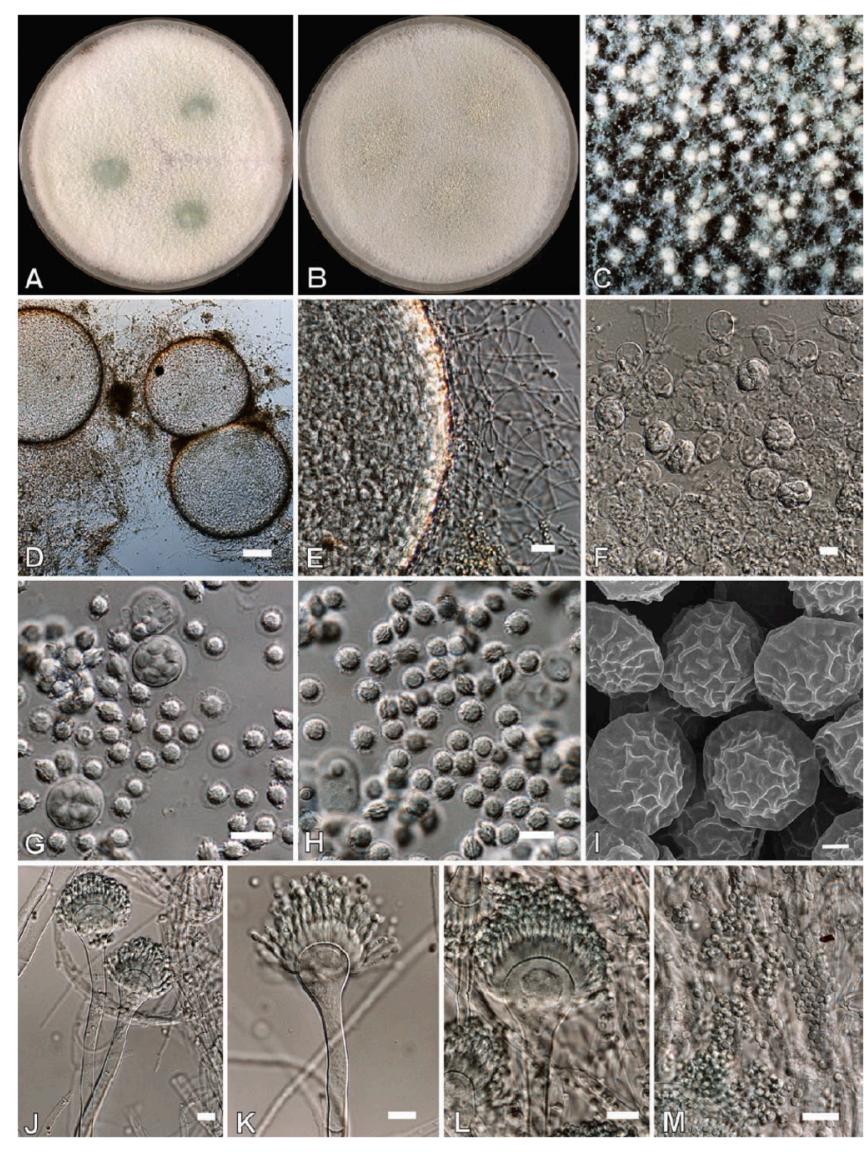

Fig. 4. Neosartorya fischeri. A-B Colonies $14 \mathrm{~d} 25^{\circ} \mathrm{C}$. A. Orange agar. B. Malt extract agar. C. Macroscopic view of the columnar conidial heads. D-E. Ascomata. F-G. Asci and ascospores. H. Ascospores. I. SEM of ascospores. J-L. Conidiophores. M. Conidia. Scale bars $=10 \mu \mathrm{m}$, except $\mathrm{D}=30 \mu \mathrm{m}, \mathrm{E}=15 \mu \mathrm{m}, \mathrm{I}=$ $1 \mu \mathrm{m}$. Fungus photos retrieved from Samson, R.A., Hong, S., Peterson, S.W., Frisvad, J.C., Varga, J., 2007. Polyphasic taxonomy of Aspergillus section Fumigati and its teleomorph Neosartorya. Studies in Mycology 59, 147-203.

smooth ornamentation (Fig. 3, photo f) (Samson et al., 2009), while $N$. fischeri ascospores are longer with 7-8 $\times 3-4 \mu \mathrm{m}$ dimensions and presenting convex surfaces bearing anastomosing ridges (reticulate) (Fig. 4, photos G-I) (Samson et al., 2007). These moulds are able to grow as low as $10-12{ }^{\circ} \mathrm{C}$ for B. nivea (Panagou et al., 2010; Kotzekidou, 2014; Lane Paixão dos Santos et al., 2020) and $10{ }^{\circ} \mathrm{C}$ for $N$. fischeri (Nielsen et al., 1989; Lane Paixão dos Santos et al., 2020), lower temperatures than bacteria. They are both able to grow under lower water activity (as low as 0.89) than bacteria (Zimmermann et al., 2011), and under reduced oxygen inside fruit packs and carbonated beverages (Sant'Ana et al., 2010). They are more resistant than other mould spores such as Penicillium and Talaromyces.

One other issue is that the germination of moulds ascospores can be triggered by the heat or pressure applied during the HPP or HPTP pasteurization process (Dijksterhuis and Teunissen, 2004; Chapman et al., 2007), which could possibly grow during storage, causing spoilage (Ferreira et al., 2011; Dijksterhuis, 2017; Rico-Munoz et al., 2019). Given the above reasons and known resistance, B. nivea or Neosartorya fischeri ascospores are proposed as reference microorganisms for the design of new HPP and HPTP pasteurization processes of fruit products.

\section{Final remarks}

Most spores investigated revealed non-linear inactivation by HPTP in fruit products, meaning they become more resistant with processing time. One other concern is the temperature abuses during storage and distribution of HPP products, which can stimulate microbial growth. These issues should be considered in the design of appropriate HPTP processing conditions, with focus on the inactivation of resistant moulds. Fruit endogenous enzymes can also be resistant to HPTP (Sulaiman et al., 2015; Terefe and Buckow, 2018; Silva and Sulaiman, 2019), but were not an objective of this study. Like microorganisms, enzyme post process activity is reduced at refrigerated temperatures used for HPP foods distribution. They should also be considered in the design of HPP or HPTP pasteurization processes for certain juices.

It is important to point out that if a fruit puree is to be pasteurized and used as ingredient in another fruit product with different properties, care should be taken. For example strawberry puree is often used as an ingredient to produce yoghurt, popsicles, smoothies, snacks, and assorted dried products. Although strawberry itself might not be problematic in terms of pathogens, the processors must ensure the final products with lower acidity using strawberry as an ingredient are properly pasteurized, to ensure the safety and stability of final product.

\section{Credit author statement}

Filipa V.M. Silva: conceptualization (idea), methodology, writing original draft preparation. Evelyn: writing - review and editing. There is no conflict of interest in this study. Part of the work was presented at XII CIBIA conference in Algarve, Portugal (2019) in the format of poster.

\section{Acknowledgements}

Part of this study was presented by Filipa V.M. Silva at XII Congresso IberoAmericano de Engenharia de Alimentos (CIBIA, IberoAmerican Congress of Food Engineering), Challenging Food Engineering as a Driver Towards Sustainable Food Processing, 1-4 July 2019, Faro, Portugal.

\section{References}

FDA, 2011. Diarrheagenic Escherichia coli (Chapter 4) In Bacteriological analytical manual.

Albrecht, J.A., Sumner, S.S., 1992. EC92-2307 Food Microbiology/Foodborne Illness. Historical Materials from University of Nebraska-Lincoln Extension. 1572. Available at: http://digitalcommons.unl.edu/extensionhist/1572.

Balda, F.P., 2018. Current status of industrial HPP equipment for food processing. In: Houška, Milan, Silva, Filipa V.M. (Eds.), High Pressure Processing of Fruit and Vegetable Products. CRC Press, pp. 73-83 (Chapter 5) in:

Beuchat, L.R., 1998. Spoilage of acid products by heat-resistant molds. Dairy, Food, Environ. Sanit. 18 (9), 588-593.

Brecht, J.K., Chau, K.V., Fonseca, S.C., Oliveira, F.A.R., Silva, F.M., Nunes, M.C.N., Bender, R.J., 2003. Maintaining optimal atmosphere conditions for fruits and vegetables throughout the postharvest handling chain. Postharvest Biol. Technol. 27 (1), 87-101.

Butz, P., Funtenberger, S., Haberditzl, T., Tauscher, B., 1996. High pressure inactivation of Byssochlamys nivea ascospores and other heat resistant moulds. LWT - Food Sci. Technol. (Lebensmittel-Wissenschaft -Technol.) 29 (5-6), 404-410.

Cerny, G., Hennlich, W., Poralla, K., 1984. Fruchtsaftverderb durch bacillen: isolierung und charakterisierung des verderbserregers. Z. Lebensm. Unters. Forsch. 179, 224-227.

Chapman, B., Winley, E., Fong, A.S.W., Hocking, A.D., Stewart, C.M., Buckle, K.A., 2007. Ascospore inactivation and germination by high pressure processing is affected by ascospore age. Innovat. Food Sci. Emerg. Technol. 8 (4), 531-534.

Deinhard, G., Blanz, P., Poralla, K., Altan, E., 1987. Bacillus acidoterrestris sp. nov., a new thermotolerant acidophile isolated from different soils. Syst. Appl. Microbiol. 10, 47-53.

Dijksterhuis, J., 2017. The fungal spore and food spoilage. Current Opinion in Food Science $17,68-74$.

Dijksterhuis, J., Teunissen, P.G.M., 2004. Dormant ascospores of Talaromyces macrosporus are activated to germinate after treatment with ultra high pressure. J. Appl. Microbiol. 96 (1), 162-169.

Dobiáš, J., Vápenka, L., 2018. Packaging system for high-pressure processing. In: Houška, Milan, Silva, Filipa V.M. (Eds.), High Pressure Processing of Fruit and Vegetable Products. CRC Press, pp. 63-72 (Chapter 4) in.

Evelyn, Silva, F.V.M., 2015a. High pressure processing of milk: modeling the inactivation of psychrotrophic Bacillus cereus spores at $38-70^{\circ} \mathrm{C}$. J. Food Eng. 165, 141-148.

Evelyn, Silva, F.V.M., 2015b. Inactivation of Byssochlamys nivea ascospores in strawberry puree by high pressure, power ultrasound and thermal processing. Int. J. Food Microbiol. 214, 129-136. 
Evelyn, Silva, F.V.M., 2016. Modeling the inactivation of psychrotrophic Bacillus cereus spores in beef slurry by $600 \mathrm{MPa}$ HPP combined with $38-70^{\circ} \mathrm{C}$ : comparing with thermal processing and estimating the energy requirements. Food Bioprod. Process. 99, 179-187.

Evelyn, Silva, F.V.M., 2017. Resistance of Byssochlamys nivea and Neosartorya fischeri mould spores of different age to high pressure thermal processing and thermosonication. J. Food Eng. 201, 9-16.

Evelyn, Silva, F.V.M., 2018. Inactivation of pathogenic microorganisms in foods by highpressure processing. In: Rai, V.R., Bai, J.A. (Eds.), Food Safety and Protection. CRC Press, pp. 343-378 (Chapter 10).

Evelyn, Silva, F.V.M., 2019. Heat assisted HPP for the inactivation of bacteria, moulds and yeast spores in foods: log reductions and mathematical models. Trends Food Sci. Technol. 88, 143-156.

Evelyn, Kim, H.J., Silva, F.V.M., 2016. Modeling the inactivation of Neosartorya fischeri ascospores in apple juice by high pressure, power ultrasound and thermal processing. Food Contr. 59, 530-537.

Ferreira, E.H.R., Rosenthal, A., Calado, V., Saraiva, J., Mendo, S., 2009. Byssochlamys nivea inactivation in pineapple juice and nectar using high pressure cycles. J. Food Eng. 95 (4), 664-669.

Ferreira, E.H.R., Masson, L.M.P., Rosenthal, A., Souza, M.L., Tashima, L., Massaguer, P. R., 2011. Thermoresistance of filamentous fungi isolated from aseptically packaged fruit nectars. Braz. J. Food Technol. 14, 164-171.

Frisvad, J.C., Samson, R.A., 1991. Mycotoxins produced by species of Penicillium and Aspergillus occurring in cereals. In: Chelkowski, J. (Ed.), Cereal Grain: Mycotoxins, Fungi, and Quality in Drying and Storage. Elsevier Science Publishers, Amsterdam, p. $441-476$.

Groot, M.N., Abee, T., Veen, H.B., 2019. Inactivation of conidia from three Penicillium spp. isolated from fruit juices by conventional and alternative mild preservation technologies and disinfection treatments. Food Microbiol. 81, 108-114.

Houbraken, J., Samson, R.A., 2017. Current taxonomy and identification of foodborne fungi. Current Opinion in Food Science 17, 84-88.

Houška, M., Pravda, P., 2018. Examples of commercial fruit and vegetable juices and smoothies cold pasteurized by high pressure. Chapter 10. In: Houška, Milan, Silva, Filipa V.M. (Eds.), High Pressure Processing of Fruit and Vegetable Products. CRC Press, pp. 147-154.

Houška, M., Silva, F.V.M., 2018. High Pressure Processing of Fruit and Vegetable Products, Contemporary Food Engineering Series. CRC Press, Taylor and Francis Group.

Hsu, H., Sheen, S., Sites, J., Huang, L., Wu, J.S., 2014. Effect of high pressure treatment on the survival of Shiga toxin-producing Escherichia coli in strawberry puree. Food Microbiol. 40, 25-30.

Huang, Y., Ye, M., Chen, H., 2013. Inactivation of Escherichia coli O157:H7 and Salmonella spp. in strawberry puree by high hydrostatic pressure with/without subsequent frozen storage. Int. J. Food Microbiol. 160, 337-343.

Hudson, J.A., Olsen, L., Cook, R., 2011. Minimum Growth Temperatures of Foodborne Pathogens and Recommended Chiller Temperatures. Ministry for Primary Industries technical paper No 2016/04, New Zealand Government.

Jain, S., Bidol, S.A., Austin, J.L., Berl, E., Elson, F., Le Maile-Williams, M., Deasy III, Moll, M.E., Rea, V., Vojdani, J.D., Yu, P.A., Hoekstra, R.M., Braden, C.R., Lynch, M. F., 2005. Multistate outbreak of Salmonella Typhimurium and Saint Paul infections associated with unpasteurized orange juice - United States. Clin. Infect. Dis. 48, 1065-1071.

Kotzekidou, P., 2014. Byssochlamys. In: Batt, C.A., Tortorello, M.L. (Eds.), Encyclopedia of Food Microbiology. Elsevier, Amsterdam, pp. 344-350.

Koutchma, T., Warriner, K., 2018. Regulatory aspects of high-pressure processed foods in North America, Europe, Asia, New Zealand, and Australia. In: Houška, Milan, Silva, Filipa V.M. (Eds.), High Pressure Processing of Fruit and Vegetable Products. CRC Press, pp. 155-168 (Chapter 11) in:

Lane Paixão dos Santos, J., Samapundo, S., van Impe, J., Sant'Ana, A.S., Devlieghere, F., 2020. Effect of sugar concentration ( ${ }^{\circ}$ Brix) and storage temperature on the time to visible growth of individual ascospores of six heat-resistant moulds isolated from fruit products, 108. Press. Food Contr.

Lopez, A., 1987. Heat penetration determinations and thermal process calculations. In: A Complete Course in Canning and Related Products. Book II: Packaging, Aseptic Processing, Ingredients. The Canning Trade, Inc., Baltimore, MD, p. 12 (Chapter 1) in.

Massaguer, P.R., Silva, A.R., Chaves, R.D., Gressoni, I., 2014. Fruit and vegetable juices. In: Batt, C.A., Tortorello, M.L. (Eds.), Encyclopedia of Food Microbiology. Elsevier, Amsterdam, pp. 992-999.

Merkulow, N., Eicher, R., Ludwig, H., 2000. Pressure inactivation of fungal spores in aqueous model solutions and in real food systems. High Pres. Res. 19 (1-6), 253-262.

Milani, E.A., Silva, F.V.M., 2016. Non-thermal pasteurization of beer by high pressure processing: modelling the inactivation of Saccharomyces cerevisiae ascospores in different alcohol beers. High Pres. Res. 36 (4), 595-609.

Milani, E.A., Ramsey, J.G., Silva, F.V.M., 2016. High pressure processing and thermosonication of beer: comparing the energy requirements and Saccharomyces cerevisiae ascospores inactivation with thermal processing and modelling. J. Food Eng. 181, 35-41.

Nielsen, P., Beuchat, L., Frisvad, J., 1989. Growth of and fumitremorgin production by Neosartorya fischeri as affected by temperature, light, and water activity. Appl. Environ. Microbiol. 54 (6), 1504-1510.

Panagou, E.Z., Chelonas, S., Chatzipavlidis, I., Nychas, G.J.E., 2010. Modelling the effect of temperature and water activity on the growth rate and growth/no growth interface of Byssochlamys fulva and Byssochlamys nivea. Food Microbiol. 27 (5), 618627.

Parish, M.E., Narciso, J.A., Friedrich, L.M., 1997. Survival of Salmonellae in orange juice. J. Food Saf. 17 (4), 273-281.

Pettipher, G.L., Osmundson, M.E., Murphy, J.M., 1997. Methods for the detection and enumeration of Alicyclobacillus acidoterrestris and investigation of growth and production of taint in fruit juice and fruit juice-containing drinks. Lett. Appl. Microbiol. 24, 185-189.

Pin, C., Baranyi, J., 2006. Kinetics of single cells: observation and modeling of a stochastic process. Appl. Environ. Microbiol. 72 (3), 2163-2169.

Pinhatti, M.E.M.C., Variane, S., Eguchi, S.Y., Manfio, G.P., 1997. Detection of acidothermophilic Bacilli in industrialized fruit juices. Fruit Process. 7, 350-353.

Raso, J., Calderón, M.L., Góngora, M., Barbosa-Cánovas, G.V., Swanson, B.G., 1998. Inactivation of Zygosaccharomyces bailii in fruit juices by heat, high hydrostatic pressure and pulsed electric fields. J. Food Sci. 63 (6), 1042-1044.

Rico-Munoz, E., Samson, R.A., Houbraken, J., 2019. Mould spoilage of foods and beverages: using the right methodology. Food Microbiol. 81, 51-62.

Samson, R.A., Hong, S., Peterson, S.W., Frisvad, J.C., Varga, J., 2007. Polyphasic taxonomy of Aspergillus section Fumigati and its teleomorph Neosartorya. Stud. Mycol. 59, 147-203.

Samson, R.A., Houbraken, J., Varga, J., Frisvad, J.C., 2009. Polyphasic taxonomy of the heat resistant ascomycete genus Byssochlamys and its Paecilomyces anamorphs. Persoonia 22, 14-27.

Sant'Ana, A., Simas, R.C., Almeida, C.A., Cabral, E.C., Rauber, R.H., Mallmann, C.A., Eberlin, M.N., Rosenthal, A., Massaguer, P.R., 2010. Influence of package, type of apple juice and temperature on the production of patulin by Byssochlamys nivea and Byssochlamys fulva. Int. J. Food Microbiol. 142 (1), 156-163.

Silva, F.V.M., Evelyn, 2018. High-pressure processing effect on microorganisms in fruit and vegetable products. In: Houška, Milan, Silva, Filipa V.M. (Eds.), High Pressure Processing of Fruit and Vegetable Products. CRC Press, pp. 3-38 (Chapter 2) in.

Silva, F.V.M., Gibbs, P.A., 2001. Alicyclobacillus acidoterrestris spores in fruit products and design of pasteurization processes. Trends Food Sci. Technol. 12 (2), 68-74.

Silva, F.V.M., Gibbs, P., 2004. Target selection in designing pasteurization processes for shelf-stable high-acid fruit products. Crit. Rev. Food Sci. Nutr. 44 (5), 353-360.

Silva, F.V.M., Gibbs, P.A., 2009. Principles of thermal processing: pasteurization. In: Simpson, R. (Ed.), Engineering Aspects of Thermal Food Processing. CRC Press, Taylor and Francis Group, Boca Raton, USA, pp. 577-595.

Silva, F.V.M., Gibbs, P.A., 2010. Non-proteolytic Clostridium botulinum spores in low-acid cold-distributed foods and design of pasteurization processes. Trends Food Sci. Technol. 12 (2), 68-74.

Silva, F.V.M., Sulaiman, A., 2019. Polyphenoloxidase in fruit and vegetables: inactivation by thermal and non-thermal processes. In: Varelis, Peter, Melton, Laurence (Eds.), Encyclopedia of Food Chemistry, vol. 2. Fereidoon Shahidi. Elsevier, pp. 287-301.

Silva, F.M., Chau, K.V., Brecht, J.K., Sargent, S.A., 1999. Tubes for modified atmosphere packaging of fresh fruits and vegetables: effective permeability measurement. Appl. Eng. Agric. 15 (4), 313-318.

Silva, F.V.M., Tan, E.K., Farid, M., 2012. Bacterial spore inactivation at $45-65^{\circ} \mathrm{C}$ using High Pressure Processing: study of Alicyclobacillus acidoterrestris in orange juice. Food Microbiol. 32 (1), 206-211.

Silva, F.V.M., Gibbs, P.A., Nunez, H., Almonacid, S., Simpson, R., 2014. Thermal processes: pasteurization. In: Batt, C.A., Tortorello, M.L. (Eds.), Encyclopedia of Food Microbiology. Elsevier, Amsterdam, pp. 577-595.

Splittstoesser, D.F., Churey, J.J., Lee, C.Y., 1994. Growth characteristics of aciduric sporeforming bacilli isolated from fruit juices. J. Food Protect. 57, 1080-1083.

Sulaiman, A., Soo, M.J., Yoon, M.M.L., Farid, M., Silva, F.V.M., 2015. Modeling the polyphenoloxidase inactivation kinetics in pear, apple and strawberry purees after High Pressure Processing. J. Food Eng. 147, 89-94.

Teo, A.Y.L., Ravishankar, S., Sizer, C.E., 2001. Effect of low-temperature, high-pressure treatment on the survival of Escherichia coli 0157:H7 and Salmonella in unpasteurized fruit juices. J. Food Protect. 64 (8), 1122-1127.

Terefe, N.S., Buckow, R., 2018. High-pressure processing effects on endogenous enzymes in fruits and vegetables. In: Houška, Milan, Silva, Filipa V.M. (Eds.), High Pressure Processing of Fruit and Vegetable Products. CRC Press, pp. 39-62 (Chapter 3) in:

van Wyk, S., Silva, F.V.M. Silva, 2017a. High pressure inactivation of Brettanomyces bruxellensis in red wine. Food Microbiol. 63 (5), 199-204.

van Wyk, S., Silva, F.V.M., 2017b. High pressure processing inactivation of Brettanomyces bruxellensis in seven different table wines. Food Contr. 81, 1-8.

van Wyk, S., Farid, M., Silva, F.V.M., 2018. $\mathrm{SO}_{2}$, high pressure processing and pulsed electric field treatments of red wine: effect on sensory, Brettanomyces inactivation and other quality parameters during one year storage. Innovat. Food Sci. Emerg. Technol. 48 (8), 204-211.

Voldřich, M., Dobiáš, J., Tichá, L., Čeřovský, M., Krátká, J., 2004. Resistance of vegetative cells and ascospores of heat resistant mould Talaromyces avellaneus to the high pressure treatment in apple juice. J. Food Eng. 61 (4), 541-543.

Weibull, W., 1951. A statistical distribution function of wide applicability. J. Appl. MechT Asme. 18 (2), 293-297.

Zimmermann, M., Miorelli, S., Massaguer, P.R., Aragão, G.M.F., 2011. Growth of Byssochlamys nivea in pineapple juice under the effect of water activity and ascospore age. Braz. J. Microbiol. 42 (1), 203-210.

Zimmermann, M., Schaffner, D.W., Aragão, G.M.F., 2013. Modeling the inactivation kinetics of Bacillus coagulans spores in tomato pulp from the combined effect of high pressure and moderate temperature. Food Science and Technology 53 (1), 107-112.

Zook, C., Parish, M., Braddock, R., Balaban, M., 1999. High pressure inactivation kinetics of Saccharomyces cerevisiae ascospores in orange and apple juices. J. Food Sci. 64 (3), $533-535$. 